\title{
Suplementasi Betain untuk Meningkatkan Performa Broiler
}

\author{
(BETAINE SUPLEMENTATION TO IMPROVE BROILER PERFORMANCE)
}

\author{
Widihantoro Gunawan Putra ${ }^{1 *}$, Ida Bagus Komang Ardana ${ }^{2}$, Hamong Suharsono ${ }^{3}$ \\ ${ }^{1}$ Mahasiswa Program Profesi Dokter Hewan, Fakultas Kedokteran Hewan Universitas \\ Udayana, Denpasar, Bali; ${ }^{2}$ Laboratorium Patologi Klinik Veteriner, Fakultas Kedokteran \\ Hewan, Universitas Udayana, Denpasar, Bali; ${ }^{3}$ Laboratorium Biokimia Veteriner, Fakultas \\ Kedokteran Hewan, Universitas Udayana, Denpasar, Bali. \\ *Email: putrawhgp@gmail.com
}

\begin{abstract}
Abstrak
Industri unggas di kota Samarinda dihadapkan dengan tingginya suhu lingkungan yang tinggi temperatur udara antara $20^{\circ} \mathrm{C}-34^{\circ} \mathrm{C}$ dengan rata-rata curah hujan per tahun $1980 \mathrm{~mm}$, dengan rata-rata kelembaban udara $85 \%$. Hal tersebut dapat mengganggu keberhasilan usaha broiler. Suhu yang tinggi memicu heat stress yang dapat mengganggu pertumbuhan ayam broiler yang berpengaruh terhadap penurunan berat badan, meningkatkan nilai Feed Conversion Ratio (FCR) dan menurunkan nilai Index Performance (IP). Penelitian ini bertujuan untuk mengetahui pengaruh pemberian betain dengan dosis berbeda melalui air minum dalam meningkatkan performa broiler meliputi berat badan, FCR dan IP. Sampel penelitian ini berjumlah 1.200 ekor broiler betina yang berumur 7 hari dengan penghitungan hasil menggunakan analisis statistik Rancangan Acak Lengkap (RAL) dengan 4 perlakuan, dosis yang digunakan yaitu; P0 $(0,0 \mathrm{~g} / \mathrm{L}), \mathrm{P} 1(0,5 \mathrm{~g} / \mathrm{L}), \mathrm{P} 2(1,0 \mathrm{~g} / \mathrm{L})$ dan P3 $(2,0 \mathrm{~g} / \mathrm{L})$. Hasil analisis statitik penelitian menunjukkan penambahan betain berpengaruh nyata $(\mathrm{P}<0,05)$ terhadap peningkatan berat badan rata-rata terbaik pada perlakuan P2 $(1,0 \mathrm{~g} / \mathrm{L}) 1,870 \pm 0,009^{\mathrm{d}}$, nilai FCR terbaik pada perlakuan $\mathrm{P} 2(1,0 \mathrm{~g} / \mathrm{L}) 1,500 \pm 0,089^{\mathrm{a}}$ dan nilai IP terbaik pada perlakuan P2 $(1,0 \mathrm{~g} / \mathrm{L}) 368,333 \pm 4,033^{\mathrm{d}}$. Betain dapat meningkatkan berat badan, mengoptimalkan FCR dan meningkatkan IP.
\end{abstract}

Kata-kata kunci: broiler; heat stress; betain, berat badan; FCR; indeks performa.

\begin{abstract}
The poultry industry in Samarinda faces high environmental temperatures with high air temperatures between $20^{\circ} \mathrm{C}-34{ }^{\circ} \mathrm{C}$ with an average rainfall per $1980 \mathrm{~mm}$, and the average humidity is $85 \%$. High temperatures can trigger heat stress that can disrupt the broiler's growth, which affects weight loss, increase FCR (feed conversion ratio) value, and decrease IP value (Performance Index). This study aims to determine the effect of giving different doses of betaine through drinking water in improving broiler performance, including weight, FCR and IP. The sample of this study amounted to 1,200 7-day old female broilers and the results were analyzed with statistical analysis of Completely Randomized Design (RAL) with four treatments, the dose used is; P0 (0.0 g/L), P1 (0.5 g/L), P2 (1.0 $\mathrm{g} / \mathrm{L})$ dan P3 $(2.0 \mathrm{~g} / \mathrm{L})$. The result of statistical analysis showed that the addition of betaine had a significant effect $(\mathrm{P}<0.05)$ for the best average weight gain on treatment $\mathrm{P} 2(1.0 \mathrm{~g} / \mathrm{L}) 1.870 \pm 0.009^{\mathrm{d}}$, the best FCR value at treatment P2 $(1.0 \mathrm{~g} / \mathrm{L}) 1.500 \pm 0.089^{\mathrm{a}}$ and the best IP value at treatment P2 (1.0 $\mathrm{g} / \mathrm{L}) 368.333 \pm 4.033^{\mathrm{d}}$. Betaine could increase weight, optimize FCR and improve IP.
\end{abstract}

Keywords: broiler; heat stress; betaine; weight; FCR; performance index.

\section{PENDAHULUAN}

Heat stress adalah masalah utama yang berdampak buruk pada performa unggas yang menyebabkan banyak respons terhadap fisiologis, endokrin dan produktivitas (Khan et al., 2012). Efek heat stress pada fisiologi unggas meliputi tidak seimbangnya asam basa dan tidak seimbangannya elektrolit (Imik et al., 2013) dan peningkatan laju respirasi, yang menyebabkan penurunan performa (Sdanhu et al., 2012), menurunkan feed intakes (Khattak et al., 2012) menghambat 
peningkatan berat badan, berat karkas, berat lemak abdomen broiler dan bahkan peningkatan angka kematian (Sdanhu et al., 2012).

Beberapa langkah telah dilakukan untuk mengurangi pengaruh heat stress pada peternakan unggas, salah satunya melalui pakan (Daghir, 1995). Banyak vitamin, suplemen, maupun zat aditif pada pakan yang memiliki efek positif terhadap heat stress pada unggas. Aditif ini termasuk elektrolit dan vitamin, serta betain (Imik et al., 2013). Betain memiliki sifat osmoproktektan yang berfungsi mengurangi efek heat stress dan menjaga keseimbangan elektrolit (Honarbakhsh et al., 2007) dan mungkin dapat memperbaiki fungsi metabolisme dan fisiologi, sehingga dapat meningkatkan performa dan efesiensi pakan broiler (Honarbakhsh et al., 2007). Zulfikri et al. (2004) juga menyatakan betain membantu menjaga osmolaritas sel dan hal tersebut dapat meningkatkan performa ayam selama terpapar heat stress. Selain itu, suplementasi betain dilaporkan dapat meningkatkan performa (Khattak et al., 2012; Suharsono et al., 2019), berat karkas (Sakomura et al., 2013) dan berat badan broiler (Rao et al., 2011).

Penelitian ini dilakukan untuk mengetahi bahwa pemberian betain dengan dosis berbeda melalui air minum dalam meningkatkan berat badan, menurunkan nilai FCR, dan meningkatkan nilai IP broiler.

\section{METODE PENELITIAN}

\section{Sampel Penelitian}

Penelitian ini menggunakan 1.200 ekor broiler betina berumur 7 hari (CP707), betain (S4), pakan pellet produksi PT. Charoen Pokphand Indonseia (kode: 510, 511 dan 512 premier) dan air minum. Peralatan yang digunakan; kandang ayam dilengkapi tempat minum otomatis, tempat makan ukuran $14 \mathrm{~kg}$ dan $7 \mathrm{~kg}$, brooder, timbangan $25 \mathrm{~kg}$, timbangan digital gantung dan Thermohygrometer.

\section{Manajemen Broiler}

Day-old chicken (DOC) diberi perlakuan dengan pemberian betain dosis 1,0gram/liter pada air minumnya sampai umur tujuh hari $(\mathrm{n}=1.200)$. Kemudian, Broiler dibagi secara acak menjadi empat kelompok berdasarkan Rancangan Acak Lengkap (RAL). Dosis yang digunakan yaitu; P0 (0,0 g/L), P1 (0,5 g/L), P2 (1,0 $\mathrm{g} / \mathrm{L}), \quad \mathrm{P} 2 \quad(2,0 \mathrm{~g} / \mathrm{L})$. Pemberian betain melalui air minum diberikan sampai umur 32 hari pemeliharaan. Betain diberikan pada siang hari dari pukul 13:00 wita sampai pukul 18:00 wita. Kebutuhan betain selama 25 hari adalah 472,5 g untuk 1200 ekor. Broiler diberi program kesehatan (vitamin dan vaksinasi) sesuai manajemen yang berlaku.

\section{Penghitungan Variabel}

Berat badan (g/ekor) diperoleh dengan cara menimbang berat badan ayam pada akhir pemeliharaan.

Berat Badan Rata - rata $=\frac{\text { Berat badan akhir pemeliharaan }}{\text { Populasi Akhir }}$

FCR dengan cara membagi total konsumsi pakan dengan total berat badan akhir pemeliharan.

Feed Convertion Ratio $=\frac{\text { jumlah } \text { konsumsi pakan }}{\text { berat badan akhir }}$

IP dengan cara sebagai berikut:

$I P=\frac{\text { rata }- \text { rata berat panen } x(100-\text { persentase kemation })}{\text { rata }- \text { rata umur panen } x F C R}$

\section{Analisis Data}

Data hasil penelitian dianalisis menggunakan sidik ragam (ANOVA) apabila terdapat perbedaan yang nyata $\mathrm{P}<$ $(0,05)$. Apabila perlakuan berpengaruh nyata maka dilanjutkan dengan Uji Duncan (Sampurna dan Nindhia, 2008).

\section{HASIL DAN PEMBAHASAN}

\section{Penambahan Berat Badan}

Pada penelitian ini didapatkan berat badan rata-rata berkisar dari 1,7 sampai 1,8 $\mathrm{kg}$ pada umur 32 hari. Kelompok broiler yang diberi tambahan betain pada air minumnya mempunyai berat yang lebih baik $(\mathrm{P}>0,05)$ dibandingkan kontrol (Tabel 
1.). Dari hasil penelitian ini berat badan rata-rata yang melampaui berat badan standar pabrik pada umur 32 hari,yaitu; P2
$(1,833 \pm 0,010 \mathrm{~kg} / \mathrm{ekor})$ dan $\mathrm{P} 3(1,870 \pm$ $0,009 \mathrm{~kg} /$ ekor) dengan standar pabrik 1,797 kg/ekor (Pokphand. 2015).

Tabel 1. Performa broiler yang diberikan betain melalui air minum.

\begin{tabular}{cccc}
\hline Dosis betain $(\mathrm{g} /$ Lair minum) & Berat Badan $(\mathrm{kg}) \pm \mathrm{SD}$ & Nilai FCR \pm SD & Nilai IP \pm SD \\
\hline P0 $(0,0)$ & $1,757 \pm 0,005^{\mathrm{a}}$ & $1,703 \pm 0,005^{\mathrm{d}}$ & $286,000 \pm 1,549^{\mathrm{a}}$ \\
P1 $(0,5)$ & $1,778 \pm 0,011^{\mathrm{b}}$ & $1,622 \pm 0,010^{\mathrm{c}}$ & $314,500 \pm 3,563^{\mathrm{b}}$ \\
P2 $(1,0)$ & $1,870 \pm 0,009^{\mathrm{d}}$ & $1,500 \pm 0,089^{\mathrm{a}}$ & $368,333 \pm 4,033^{\mathrm{d}}$ \\
P3 $(2,0)$ & $1,833 \pm 0,010^{\mathrm{c}}$ & $1,543 \pm 0,005^{\mathrm{b}}$ & $348,000 \pm 3,098^{\mathrm{c}}$ \\
\hline Signifikan & 0,000 & 0,000 & 0,000
\end{tabular}

$\begin{array}{llll}\text { Signifikansi } & 0,000 & 0,000 & 0,000\end{array}$

Keterangan: Nilai dengan superskrip huruf yang tidak sama menunjukkan perbedaan nyata $(\mathrm{P}<0,05)$.

Sun et al. (2008) dan Rafique et al. (2000) menunjukkan bahwa suplementasi Betain dapat menggantikan $25 \%$ dari total kebutuhan metionin pada pertumbuhan ayam pedaging. Perlakuan dengan penambahan betain pada air minum mampu meningkatkan nafsu makan ayam saat dalam cekaman panas. Betain juga digunakan oleh berbagai jaringan sebagai osmolyte (Law dan Burg, 1991), menurut (Eklund et al., 2005) karena sifat osmotiknya, Betain memiliki potensi untuk meningkatkan daya cerna nutrisi dalam usus. Selain itu, betain terlibat dalam protein dan energi metabolisme karena fungsinya sebagai gugus donor metil. Virtanen dan Rosi (1995) menyimpulkan bahwa suplementasi betain dan metionin memiliki tingkatan efektivitas yang sama dalam pertumbuhan. Menurut Jull (1992) menyatakan bahwa kecepatan pertumbuhan merupakan faktor penting yang mempengaruhi berat badan, dimana semakin tinggi berat badan mengakibatkan peningkatan konversi pakan yang tinggi. Semakin tinggi berat badan hidup yang didapat semakin tinggi karkas yang dihasilkan.

\section{Feed Conversion Ratio (FCR)}

Penambahan betain pada air minum broiler memberi efek positif terhadap FCR $(\mathrm{P}>0,05)$ dibanding dengan kelompok kontrol. Nilai FCR terburuk $(1,704)$ pada broiler tanpa suplementasi dibandingkan dengan Nila FCR terbaik P2 $(1,500)$ dengan suplementasi 1,0 g/L (Tabel 1.).
Dari hasil penelitian nilai FCR yang melampaui nilai FRC standar pabrik pada umur 32 hari,yaitu; P2 $(1,500 \pm 0,089)$ dan P3 (1,543 $\pm 0,005)$, dengan nilai FCR standar pabrik 1, 54 g/ekor (Pokphand, 2015). Menurunya nilai FCR mungkin disebabkan oleh meningkatnya pertambahan berat badan, karena FCR diperoleh dari pertambahan berat badan dibagi dengan konsumsi pakan. Hasil analisis statistik yang menunjukkan perlakuan memberikan pengaruh yang berbeda nyata disebabkan oleh beberapa faktor diantaranya palatabilitas terhadap pakan dan air minum yang dikonsumsi oleh ayam. Menurut Aisjah et al. (2007) menunjukkan bahwa suplementasi metionin sintetis sebanyak $1,0 \mathrm{~g} / \mathrm{L}$ pada air minum mengakibatkan pertambahan berat badan yang lebih tinggi daripada suplementasi metionin pada tingkat $0,5 \mathrm{~g} / \mathrm{L}$ dan 2,0 g/L. Hal ini yang menyebabkan kadar Betain pada air minum yang mengandung metionin dengan dosis tepat menghasilkan berat badan yang tinggi, dosis betain yang melebihi ataupun kurang dari kebutuhan menghasilkan berat badan yang menurun.

Pertambahan berat badan dipengaruhi oleh konsumsi pakan, hal ini sesuai dengan pendapat Zahra (1996) yang menyatakan bahwa tingkat konsumsi pakan erat hubungannya dengan pertumbuhan, semakin baik osmoregulasi didalam tubuh ayam semakin tinggi berat badan yang dihasilkan. Penelitian Ratriyanto et al., (2009) menunjukkan bahwa rendahnya 
performa pertumbuhan pada defisiensi metionin yang disuplementasi betain diduga karena jumlah akseptor gugus metil lebih sedikit dibandingkan dengan banyaknya donor gugus metil. Hal ini disebabkan Betain sebagai donor gugus metil memerlukan akseptor yang dapat menangkap gugus metil dari Betain. Dari hasil penelitian menunjukkan bahwa pertambahan berat badan tertinggi pada perlakuan P2 $(1,870 \pm 0,009)$ dikarenakan pakan yang dikonsumsi menjadi daging didalam tubuh ayam, perlakuan dengan penambahan betain mampu meningkatkan nafsu makan ayam saat dalam cekaman panas, sehingga pertambahan berat badan juga tinggi. Hal ini menunjukkan bahwa Betain dapat menjadi methyl donor yang efektif sebagai pengganti methionin.

Nilai FCR terbaik pada penelitian ini adalah P2 (1,500 $\pm 0,089)$ konversi pakan pada P0 dan P3 yang masih tinggi disebabkan oleh keseimbangan pakan yang dikonsumsi dengan pertambahan berat badan. Hal ini sependapat dengan Suprijatna (2005) yang menyatakan bahwa konversi pakan sebagai tolak ukur untuk menilai seberapa banyak pakan yang dikonsumsi ayam menjadi jaringan tubuh, yang dinyatakan dengan besarnya berat badan, ini adalah cara yang masih dianggap terbaik. Semakin rendah nilai FCR maka ternak tersebut semakin efisien dalam merubah pakan menjadi jaringan tubuh.

\section{Index Performance (IP)}

Indeks Performa broiler menjadi lebih baik setelah diberi suplemen betain ( $\mathrm{P}>0,05)$. Nilai IP kelompok P2 $(368,333)$ jauh melampaui standar pabrik sebesar 348 (Pokphand, 2015), sementara kelompok P3 mempunyai nilai IP yang sama (Tabel 1.).

Perlakuan dengan penambahan Betain pada air minum mampu meningkatkan nafsu makan ayam yang berpengaruh terhadap nilai IP. Faktor-faktor yang mempengaruhi nilai IP adalah tingkat mortalitas dan morbiditas yang rendah, umur rata-rata panen yang cepat, berat badan rata-rata ayam saat panen yang berbanding lurus dengan FCR yang akan menghasilkan nilai IP yang tinggi (Pokphand, 2015). Selain kandungan energi yang cukup pada pakan, manejemen kandang, suhu lingkungan dan kondisi kesehatan. Penelitian Tolba et al. (2007) menunjukan bahwa suplement Betain memperbaiki FCR dan berat badan di bandingkan dengan perlakuan kontrol.

Hal tersebut dikuatkan dengan pendapat Honarbakhsh et al. (2007) yang menyatakan bahwa betain meningkatkan berat badan dan memperbaiki FCR pada ayam broiler pada priode grower dan finisher. Fungsi betain sebagai osmolit yang dapat memperbaiki struktur usus dan fungsi untuk meningkatkan pertumbuhan ayam broiler. Hal ini juga menunjang dalam perbaikan nilai IP yang baik. Selain itu kandungan energi yang baik pada pakan, manajemen kandang, kondisi kesehatan ayam juga sangat menunjang nilai IP yang baik.

\section{SIMPULAN DAN SARAN}

\section{Simpulan}

Suplementasi betain melalui air minum dapat meningkatkan berat badan, menurunkan nilai FCR, dan meningkatkan nilai IP broiler. Perlakuan terbaik pada pemberian $1,0 \mathrm{~g} / \mathrm{L}$, dengan berat badan broiler $1,870 \mathrm{~kg}$, nilai FCR 1,500, dan IP 368,33 .

\section{Saran}

Disarankan menggunakan betain $1 \mathrm{~g} / \mathrm{L}$ dalam air minum yang sesuai dengan kebutuhan ayam broiler.

\section{UCAPAN TERIMAKASIH}

Ucapan terimakasih disampaikan kepada peternakan broiler Heri Farm, Samarinda yang telah memberikan fasilitas serta semua pihak yang telah bersedia membantu sehingga penelitian ini dapat terlaksana. 


\section{DAFTAR PUSTAKA}

Aisjah T, Wiradimadja R, Abun. 2007. Suplementasi metionin dalam ransum berbasis lokal terhadap imbangan efisiensi protein pada ayam pedaging. Skripsi. Universitas Padjajaran.

Daghir NJ. 1995. Poultry production in hot climates. CABI Publishing, The University Press, Cambridge, UK.

Eklund M, Bauer E, J Wamatu J, Mosenthin R. 2005. Potential nutritional and physiological functions of betaine in livestock. Nutr. Res. Rev. 18: 31-48.

Honarbakhsh S, Zaghari M, Shivayad, M. 2007. Interactive effects of dietary betaine and saline water on carcass traits of broiler chicks. J. Biol. Sci. 7:1208-1214

Imik H, Kaynar O, Ozkanlar S, Gumus R, Polat H dan Ozkanlar Y. 2013. Effects of vitamin c and alipoid acid dietary supplementations on metabolic adaptation of broilers to heat stress. Revue. Méd. Vét. 164: 52-59.

Jull MA. 1992. Poultry Husbendry. $3^{\text {rd }}$ Ed. McGraw Hill Publishing Company. New Delhi.

Khan R, Naz S, Nikousefat Z, Selvaggi M, Laudadio V dan Tufarelli V. 2012. Effect of ascorbic acid in heat stressed poultry. Worlds Poult. Sci. 68: 477489.

Khattak FM, Acamovic T, Sparks N. 2012. Comparative efficacy of different supplements used to reduce heat stress in broilers. Pak. J. Zool. 44: 31-41.

Law RO, Burg MB. 1991. The role of organic osmolytes in the regulation of mammalian cell volume. Adv. Comp. Environ. Physiol. 9: 189-225.

Pokphand C. 2015 Standar Manajemen Ayam Broiler. Indonesia.

Rafique M, Pasha AK, Mahmud A. 2000. Biological availability of Betain for methionine sparing in broiler chickens. Int. J. Agri. Biol. 2(12): 165-166.

Rao SVR, Raju MVLN, Panda AK, Saharia P, Sunder GS. 2011. Effect of supplementing betaine on performance, carcass traits and immune responses in broiler chicken fed diets containing different concentration of methionine. Asian-Australasian J. Anim. Sci. 24: 662-669.

Ratriyanto A, Mosenthin M, Bauer E, Eklund M. 2009. Metabolic, osmoregulatory and nutritional functions of betain in monogastric animals. Asian-Australasian J. Anim. Sci. 22: 1461-76.

Sakomura NK, Barbosa NAA, Longo FA, EP da Silva, Bonato MA, Ferndanes JBK. 2014. Effect of dietary betaine supplementation on the performance, carcass yield, and intestinal morphometrics of broilers submitted to heat stress. Brazilian J. Poult. Sci. 15(2): 105-112.

Sampurna IP, Nindhia TS. 2008. Analisis Data dengan SPSS dalam Rancangan Percobaan. Udayana Unibersity Press.

Sdanhu MA, Mirza FQ, Afzal F, Mukhtar N. 2012. Effect of heat stress on cellular dan humoral immunity and its cure with atocopherol in meat type birds. Livest. Sci. 148: 181-188.

Suharsono H, Putra IBPS, Ardana IBK, Gunawan IWNF, Sudipa PH, Agustina KK. 2019. Increasing eggs protein level and eggshell integrality performed by addition of xylanase, amylase, protease (avizyme® 1502) in layers feed. $J . A d v$. Agric. 10:1623-1628.

Sun H, Yang WR, Yang ZB, Wang Y, Jiang SZ, Zhang GG. 2008. Effects of betaine supplementation to methionine deficient diet on growth performance and carcass characteristics o broilers. American J. Anim. Vet. Sci. 3(3): 78-84.

Suprijatna E, Umiyati A, Ruhyat K. 2005. Ilmu Dasar Ternak Unggas. Penebar Swadaya. Jakarta.

Tolba AAS, Shabaan MM, Wagdy AZ. 2007. Improvement of fayomi laying hens performance under hot climate conditions: 2. Betaine, folic acid and choline. Egypt. Poult. Sci., 27(1): 2135.

Virtanen E, Mcnaughton J, Rosi L, Hall D. 1993. Effect of betain suplementation 
on intestinal lessions, mortality and performance of coccia-challenged broiler chick. Proc. $9^{\text {th }}$ Eur. Symp. Poult. Nutr., Jelenia Gora, Poland. Pp. 433-435.

Zahra T. 1996. Pengaruh berbagai tingkat penggunaan protein dan kepadatan kandang terhadap performans ayam ras petelur pada fase produksi. Skripsi. Fakultas Peternakan Universitas Andalas. Padang.

Zulkifli I, Mysahra SA, Jin LZ. 2004. Effect of betaine on growth performance and carcass characteristics in growing pigs. Asain-Aust. J. Anim. Sci. 17(2): 224249. 